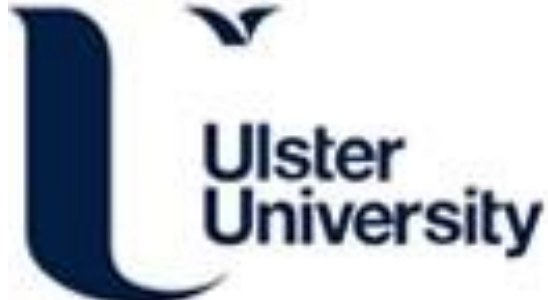

\section{Response of microbial community structure to microbial plugging in a mesothermic petroleum reservoir in China}

Banat, I. (2010). Response of microbial community structure to microbial plugging in a mesothermic petroleum reservoir in China. Appl Microbiol Biotechnol, 88, 1413-1422. https://doi.org/10.1007/s00253-010-2841-7

Link to publication record in Ulster University Research Portal

\section{Published in:}

Appl Microbiol Biotechnol

Publication Status:

Published (in print/issue): 01/01/2010

DOI:

10.1007/s00253-010-2841-7

\section{Document Version}

Publisher's PDF, also known as Version of record

\section{General rights}

Copyright for the publications made accessible via Ulster University's Research Portal is retained by the author(s) and / or other copyright owners and it is a condition of accessing these publications that users recognise and abide by the legal requirements associated with these rights.

\section{Take down policy}

The Research Portal is Ulster University's institutional repository that provides access to Ulster's research outputs. Every effort has been made to ensure that content in the Research Portal does not infringe any person's rights, or applicable UK laws. If you discover content in the Research Portal that you believe breaches copyright or violates any law, please contact pure-support@ulster.ac.uk. 


\title{
Response of microbial community structure to microbial plugging in a mesothermic petroleum reservoir in China
}

\author{
Fan Zhang • Yue Hui She $\cdot$ Sha Sha Ma $\cdot$ Ji Ming Hu • \\ Ibrahim M. Banat • Du Jie Hou
}

Received: 29 June 2010 /Revised: 11 August 2010 /Accepted: 12 August 2010 /Published online: 28 August 2010

(C) Springer-Verlag 2010

\begin{abstract}
Microbial plugging, a microbial enhancement of oil recovery (MEOR) technique, has been applied in a candidate oil reservoir of Daqing Oil Field (China). The goal of this study is to monitor the survival of injected bacteria and reveal the response of microbial communities in field trial of microbial plugging through injection of selected microbial culture broth and nutrients. Culturedependent enrichment and culture-independent 16S rDNA clone library methods were used. The results show that it was easy to activate targeted biopolymer-producing bacteria in a laboratory environment, and it was difficult for injected exogenous bacteria to survive. In addition, microbial communities in the oil reservoir also changed before and
\end{abstract}

F. Zhang $(\bowtie) \cdot$ D. J. Hou $(\bowtie)$

The Key Laboratory of Marine Reservoir Evolution and

Hydrocarbon Accumulation Mechanism, Ministry of Education,

School of Energy Resources,

China University of Geosciences (Beijing),

Beijing 100083, China

e-mail: fanzhang123@126.com

e-mail: hdj@cugb.edu.cn

Y. H. She $(\bowtie) \cdot J$. M. Hu

College of Chemistry and Molecular Sciences, Wuhan University, Wuhan 430072, China

e-mail: sheyuehui@263.net

Y. H. She · S. S. Ma

College of Chemistry and Environmental Engineering,

Yangtze University,

Jingzhou, Hubei 434023, China

I. M. Banat

School of Biomedical Sciences, University of Ulster,

Coleraine BT52 ISA N. Ireland, UK after the field trial. However, microbial communities, activated by fermentative medium for biopolymerproducing bacteria, appeared to show greater differences in the laboratory than in the natural reservoir. It was concluded that microbial populations monitoring was important to MEOR; results of response of microbial communities could provide a guide for the future field trials.

Keywords Microbial plugging $\cdot$ Microbial enhancement of oil recovery (MEOR) - Microbial communities · Biopolymer-producing bacteria . $16 \mathrm{~S}$ rDNA clone library

\section{Introduction}

After water flooding which is a preferred secondary oil production technique (Planckaert 2005), new and innovative enhanced oil recovery (EOR) techniques that increase recovery factors in oil reservoirs are dictated to meet the increase in energy demand. Besides chemical and physical EOR technologies, microbial EOR (MEOR) processes are gaining increased attention by researchers and oil companies due to their economic and environmentally friendly advantages (Banat et al. 2010). Current knowledge of MEOR includes: (1) nitrate and/or nitrite controls for $\mathrm{H}_{2} \mathrm{~S}$ production, (2) air injection stimulates the metabolism of hydrocarbons and helps mobilization of crude oil, (3) fermentative bacterial broth and nutrient injection produce potential metabolites that can increase oil recovery (Youssef et al. 2009). Microbial plugging is a specific MEOR method aimed at improving sweep efficiency by occluding preferential flow paths known as thief zones (Abdul and Farouq Ali 2003; Usman 2009). This MEOR method is 
based on the knowledge that fermentative broth and nutrient of microbial polymers are injected into oil reservoirs to reduce viscous fingering and stimulate the in situ growth of microorganisms in high-permeability zones, respectively (Brown et al. 2002; Khachatoorian et al. 2003).

Bacteria that are used widely in microbial plugging in laboratory and field trials are Enterobacter cloacae (Ohno et al. 1999; Nagase et al. 2001) and Bacillus licheniformis (Yakimov et al. 1997; Maezumi et al. 1998). Biopolymers or microbial biomass produced by these bacteria work as plugging agents to reduce flow in high-permeability zones and thereby redirect the displacement fluid into previously by-passed portions of reservoirs (Vossoughi 2000; Abdul and Farouq Ali 2003). In addition, special nutrients injected into reservoirs always preferentially reach highpermeability regions (Banat 1995). Thus, the growth of indigenous microorganisms that can metabolize these nutrients are stimulated in high-permeability zones or dominant flow channels, which reduces the movement of water in these regions of oil reservoirs (Brown 1984; Bailey et al. 2000).

Numerous laboratory studies and field trials indicate that the use of microbial plugging is effective in stimulating oil recovery (Sheehy et al. 1992, Sheehy 1991; Maezumi et al. 1998; Stewart and Fogler 2001, Stewart and Fogler 2002; Nagase et al. 2001, 2002). However, the main areas of investigation were related to monitoring permeability reduction of sandstone cores, increase of oil production, and reduction of water production. Few studies monitored microbial communities before and after microbial plugging to assess the effect of microbial treatments. Whether microbial communities in a reservoir under field trial will vary after the injection of fermentation broth of bacterial cultures and nutrients to stimulate the growth bacteria, remains unknown. In addition, whether targeted microbes that enhance oil recovery are activated in natural environments after injection of nutrients have not yet been quantified. Also, the existence and character of differences in microbial communities grown in laboratories versus oil reservoirs have not been measured. Answers to these questions are key factors in the assessment of microbial treatments and could formulate guides for further fieldwork to improve both understanding of the process and identify ways of enhancing its effectiveness. Therefore, a comprehensive assessment of microbial communities before and after microbial field trials is of practical importance for future applications of MEOR. The culture-independent molecular method based on 16S rDNA has been proven effective as a basis for understanding microbial communities in different environments. Studies associated with microbial communities of petroleum reservoirs have also been reported (Orphan et al. 2000; Grabowski et al. 2005; Li et al. 2007; Dahle et al. 2008; Lysnes et al. 2009).
However, monitoring microbial communities during MEOR field trials has been much less reported.

A microbial plugging field trial was carried out in Daqing Oil Field (China) from December 2008 to April 2009. In order to gain insight and some answers to the above questions, wellhead samples of producing wells were collected at different time intervals before and after the field trial, and microbial communities of original samples and enrichment samples were analyzed. Changes in microbial communities due to microbial plugging were evaluated. Results would have very significant values to guide the next field trials of microbial plugging in this oil field.

\section{Materials and methods}

Field site and sampling

A block of field trials with an area of $0.72 \mathrm{~km}^{2}$ is located in the north of the Daqing Oil Field (China). Oil production at this block commenced in 1964; the original oil in place (OOIP) is approximately $175.04 \times 10^{4} \mathrm{t}$ with a current OOIP recovery of $55.28 \%$. Formation pressure increases from 11.19 $\mathrm{MPa}$ to $11.62 \mathrm{MPa}$, and the temperature of this reservoir is approximately $45^{\circ} \mathrm{C}$. Five-spot well patterns are applied in six injection wells and 11 production wells in this block (Fig. 1).

A total of $10,000 \mathrm{~m}^{3}$ fermentative cultures of indigenous bacterium of $B$. licheniformis DM-1 (DQ539620) and exogenous bacterium of E. cloacae XW (EF592491) and nutrients were injected into the study reservoir from

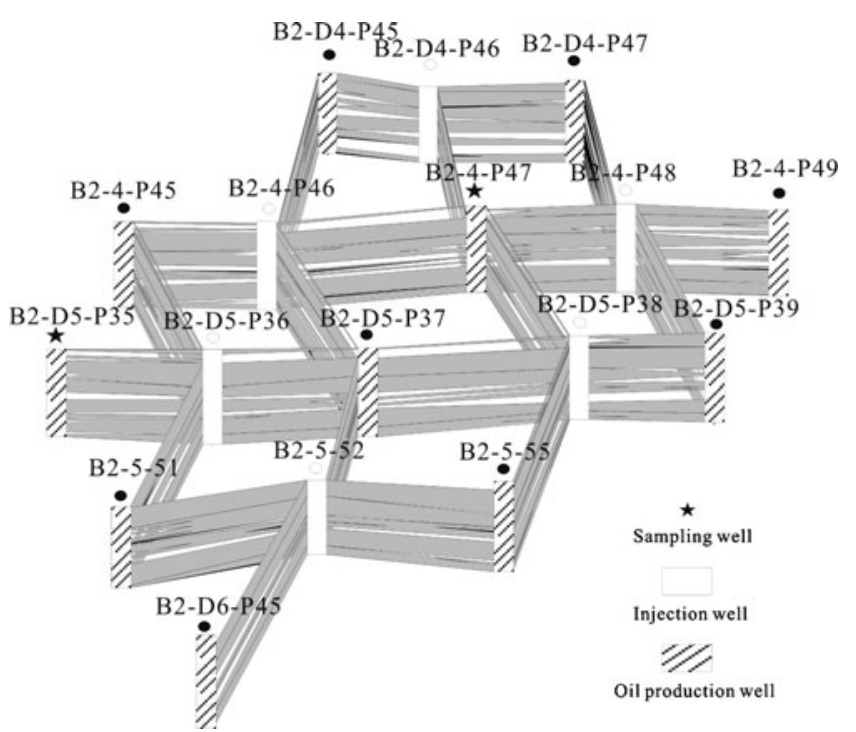

Fig. 1 Five-spot well patterns applied in six injection wells and 11 production wells in the studied block of Daqing Oil Field (China). The white parts between wells represent the continuity of the studied reservoir 
December 2008 to April 2009 (data provided by Daqing Petroleum Group Ltd.). Water-oil samples were retrieved from wellheads of two production wells, B2-4-P47 and B2D5-P35 located in the centre and fringe of the study block respectively, in October 2008, February 2009, and June 2009. Samples were collected in sterile plastic bottles and transported to the laboratory as fast as possible for culture and molecular analyses. In this study, A and B represent the production wells B2-4-P47 and B2-D5-P35, respectively; 1, 2 , and 3 represent the three different sampling times (October 2008, February 2009, and June 2009).

\section{Enrichment of biopolymer-producing bacteria}

The fermentative medium of biopolymer-producing bacteria provided by Daqing Petroleum Group Ltd. was used. The medium contains, per litre, $20 \mathrm{~g}$ sucrose, $2 \mathrm{~g} \mathrm{KH}_{2} \mathrm{PO}_{4}$, $1 \mathrm{~g} \mathrm{MgSO}_{4}, 1 \mathrm{~g}\left(\mathrm{NH}_{4}\right)_{2} \mathrm{SO}_{4}$. The $\mathrm{pH}$ was adjusted to 7.0. Water-oil samples were inoculated in the proportion of 5:100 $(v / v)$. Enrichment cultures were cultivated at $45^{\circ} \mathrm{C}$ (the reservoir temperature) and $150 \mathrm{rmp}$ for 4 days.

\section{DNA extraction}

For water-oil samples, a $50 \mathrm{ml}$ sample was centrifuged $(10,000 \times g ; 8 \mathrm{~min})$ to pellet cells, and for enrichment cultures and positive clone cultures, $2 \mathrm{ml}$ samples were sufficient. Following the manufacturer's protocol for the FastDNA Spin Kit for Soil (Qbiogen, Carlsbad, CA, USA), genomic DNA was extracted from collected cells. Extracted DNA was detected by agarose gel electrophoresis.

\section{Amplification of 16S rRNA gene}

The 16S rDNA in the bulk DNA was amplified by the polymerase chain reaction (PCR) reacting system of $25 \mu \mathrm{l}$ including a $2.5 \mu \mathrm{L}$ of $10 \times \mathrm{PCR}$ buffer (Mg2+ plus), $10 \mathrm{nmol}$ of deoxynucleotide triphosphates, $1 \mathrm{U}$ Taq DNA polymerase (TakaRa), and $10 \mathrm{pmol}$ of each universal bacteria-specific primer, 27F (5'- AGAGTTTGATCCTGGCTCAG -3') and 1492r (5'-CTACGGCTACCTTGTTACG A-3'). The thermal cycler program involved an initial denaturation at $94^{\circ} \mathrm{C}$ for $5 \mathrm{~min}, 40$ cycles of $94^{\circ} \mathrm{C}$ for $30 \mathrm{~s}, 56^{\circ} \mathrm{C}$ for $60 \mathrm{~s}, 72^{\circ} \mathrm{C}$ for $90 \mathrm{~s}$, and a final extension step of $72^{\circ} \mathrm{C}$ for $10 \mathrm{~min}$ (Zhang et al. 2010). The amplified fragments were approximately $1,450 \mathrm{bp}$

Construction of 16S rRNA gene libraries

The obtained PCR products were purified with an Agarose Gel DNA Purification Kit (TianGen Biotech, Beijing, China) and ligated into a PGEM-T Easy Vector (Promega, Madison, WI, USA) as introduced by the suppliers. The ligated products were transformed into Trans1-T1 competent cells (TransGen
Biotech, Beijing, China) using chemical transformation. $50 \mu \mathrm{l}$ cells, incubated for $1 \mathrm{~h}$ at $37^{\circ} \mathrm{C}$, were spread on LB plates containing ampicillin $(100 \mu \mathrm{g} / \mathrm{ml})$, IPTG $(50 \mathrm{mM})$, and X-Gal $(80 \mu \mathrm{g} / \mathrm{ml})$. One hundred putative clones (white) from each plate were transferred to another labelled LB plate with ampicillin $(100 \mu \mathrm{g} / \mathrm{ml})$. A re-amplification, with sets of vector-specific primers T7/SP6, was taken to determine positive clones. Minimum cells of putative clones were used as templates in reaction mixtures during the re-amplification procedure. PCR products of positive clones were subjected to amplified ribosomal DNA restriction analysis (ARDRA) (Lagacé et al. 2004) with HinfI and HaeIII (TaKaRa). Clones with identical ARDRA profiles were classified into one operational taxonomic unit (OTU). Representative clones, belonging to different OTUs, were selected for sequencing. Clone libraries were statistically evaluated by rarefaction analysis using Analytic Rarefaction 1.3 (http://www.uga.edu/ strata/software/Software.html) software in which the expected numbers of different ARDRA groups versus the numbers of positive clones in each library were calculated.

Sequencing was performed on an ABI PRISM 3730 DNA sequencer (SinoGenoMax Co., Ltd., Beijing, China). The obtained sequences were manually checked and edited using DNAMAN version 5.2.2.0. The partial sequences were submitted to the GenBank database of the National Center for Biotechnology Information (http://www.ncbi.nlm.gov) employing the Basic Local Alignment Search Tool algorithm to determine their phylogenetic affiliation. The sequences being the nearest neighbours of the submitted sequences were cited from the GenBank in order to construct neighbourjoining trees using DNAMAN software, version 5.2.2.0.

Nucleotide sequence accession numbers

16S rRNA gene sequences, submitted to the GenBank, have been assigned accession numbers: HM593791-HM593819 (environmental samples of production well B2-4-P47), HM593820-HM593858 (environmental samples of production well B2-D5-P35), HM593859-HM593867 (biopolymerproducing bacteria enrichments).

\section{Results}

Biopolymer-producing bacterial enrichment cultures

Wellhead samples of the production wells B2-5-P35 and B24-P45 at different sampling times were inoculated into the fermentative medium for biopolymer-producing bacteria in the laboratory. After $36 \mathrm{~h}$, the concentration of bacteria reached the highest peak of $10^{8} \mathrm{cells} / \mathrm{ml}$ through microscopic examination, and all enrichment cultures created viscous white products that did not separate by shaking the bottles, 
which is in keeping with previous studies of biopolymerproducing bacteria (Cheng et al. 2007). Six enrichment cultures (PA1, PA2, PA3, PB1, PB2, and PB3) were obtained at $45^{\circ} \mathrm{C}$ successfully.

Clone libraries of biopolymer-producing bacterial enrichment cultures

Six biopolymer-producing bacterial clone libraries (PA1, PA2, PA3, PB1, PB2, and PB3) based on 16S rRNA genes were constructed. According to ARDRA of approximately 50 positive clones in each library, microbial diversity in the six clone libraries appeared low with 3-4 OTUs. The DNA sequences of microbial communities in the six clone libraries were affiliated with Brevibacillus agri, B. licheniformis, and Pseudomonas aeruginosa. All the analyzed sequences had high similarity (more than 98\%) with reported cultured bacteria (Table 1). In addition, there was very little difference in microbial populations detected in the enrichment cultures of B2-D5-P35. In comparison, the enrichment cultures of B2-4-P47, during injection of fermentative cultures, microbial populations of $B$. licheniformis replaced the dominant status of B. agri in the clone libraries. Before the field trial, B. licheniformis were detected in the enrichment cultures indicating the group of bacteria was indigenous. The exogenous microbial population of E. cloacae was missing from all clone libraries, which indicated that E. cloacae did not survive in the reservoir environment. The microbial group of B. agri appeared and was dominant in all enrichment cultures, suggesting that the fermentative medium applied in Daqing Oil Field was able to support the growth of the indigenous bacterium $B$. agri in the laboratory.

Microbial diversity in the oil reservoir before the field trial of microbial plugging

Before microbial plugging, two clone libraries (A1 and B1) of wellhead samples of the production wells of B2-4-P47 and
B2-D5-P35 were constructed to represent microbial communities in the oil reservoir. According to ARDAR of approximately 100 positive clones in each library, sequences in the clone libraries $\mathrm{A} 1$ and $\mathrm{B} 1$ were assigned to nine and 16 unique phylotypes, respectively.

Clone library A1 was, on the whole, dominated by sequences affiliated with Brevundimonas, which is followed by Thauera and Uncultured Candidate division. The other closest bacteria related to A1 are displayed in Fig 2. The closest bacteria affiliated with clone library B1 were less similar to those in the A1 library; uncultured bacteria occupying the greater percentage of the diversity but also included Bacteroidetes. Sequences affiliated with cultured bacteria were Hyphomonas polymorpha, Agrobacterium, and Sulfuricuruum (Fig. 3).

Microbial diversity in the oil reservoir during the field trial of microbial plugging

Microbial plugging was carried out from December 2008 to April 2009. Samples of both studied production wells were collected on February 27, 2009. Based on ARDAR of 200 positive clones, two clone libraries (A2 and B2) containing 8 and 16 unique phylotypes, respectively, were constructed. The major groups of phylotypes in the clone library A2 were Brevundimonas, Pseudomonas, and uncultured Bacteroidetes bacterium (Fig. 2). The dominant microbial communities of B2 were Pseudomonas stutzeri, Brevundimonas, Sphingomonas, and uncultured bacterium (Fig. 3).

Microbial diversity in the oil reservoir after the field trial of microbial plugging

Two last clone libraries (A3 and B3) with 12 and 8 OTUs, respectively, were constructed from the samples collected 2 months after microbial plugging. Pseudomonas-affiliated sequences in A3 were abundant; other bacterial communities of A3 were benzene mineralizing consortium, Sphingomonas, and candidate division (Fig. 3). Dominant microbial commu-
Table 1 Closest cultured strains for clone libraries of biopolymer-producing bacterial enrichment cultures
Closest cultured strains

Closest cultured strains

Clone libraries

\begin{tabular}{llllll}
\hline PA1 PA2 & PA3 & PB1 & PB2 & PB3 \\
\hline Richness $^{\mathrm{a}}(\%)$ & & & &
\end{tabular}

\begin{tabular}{|c|c|c|c|c|c|c|c|}
\hline Brevibacillus agri AB039334 & 99 & & & & 69 & 77 & 74 \\
\hline Brevibacillus agri AY319301 & 99 & 69 & 7 & 41 & 8 & 11 & 12 \\
\hline Brevibacillus agri FJ592179 & 99 & & & & 9 & & 7 \\
\hline Bacillus licheniformis EU344793 & 99 & & & & 14 & 12 & 7 \\
\hline Bacillus licheniformis EU718490 & 99 & & 9 & 13 & & & \\
\hline Bacillus licheniformis EU373408 & 99 & 23 & 84 & 34 & & & \\
\hline Pseudomonas aeruginosa GQ180118 & 99 & 7 & & 12 & & & \\
\hline
\end{tabular}

\footnotetext{
${ }^{\text {a }}$ The percentage of clone numbers of each OUT occupied the whole positive clones in a library
} 
Fig. 2 Phylogenetic tree of bacteria 16S rDNA phylotypes of clone libraries $A 1, A 2$, and $A 3$ constructed from oil-water samples from oil production well of B2-4-P47. The tree was based on partial $16 \mathrm{~S}$ rDNA genes (approximately $800 \mathrm{bp}$ ) and the nearest clones retrieved from GenBank database. Bootstrap values $(>60 \%)$ are attached at branch points. The scale bar represents $5 \%$ estimated sequence divergence

$$
\text { 0.05 }
$$

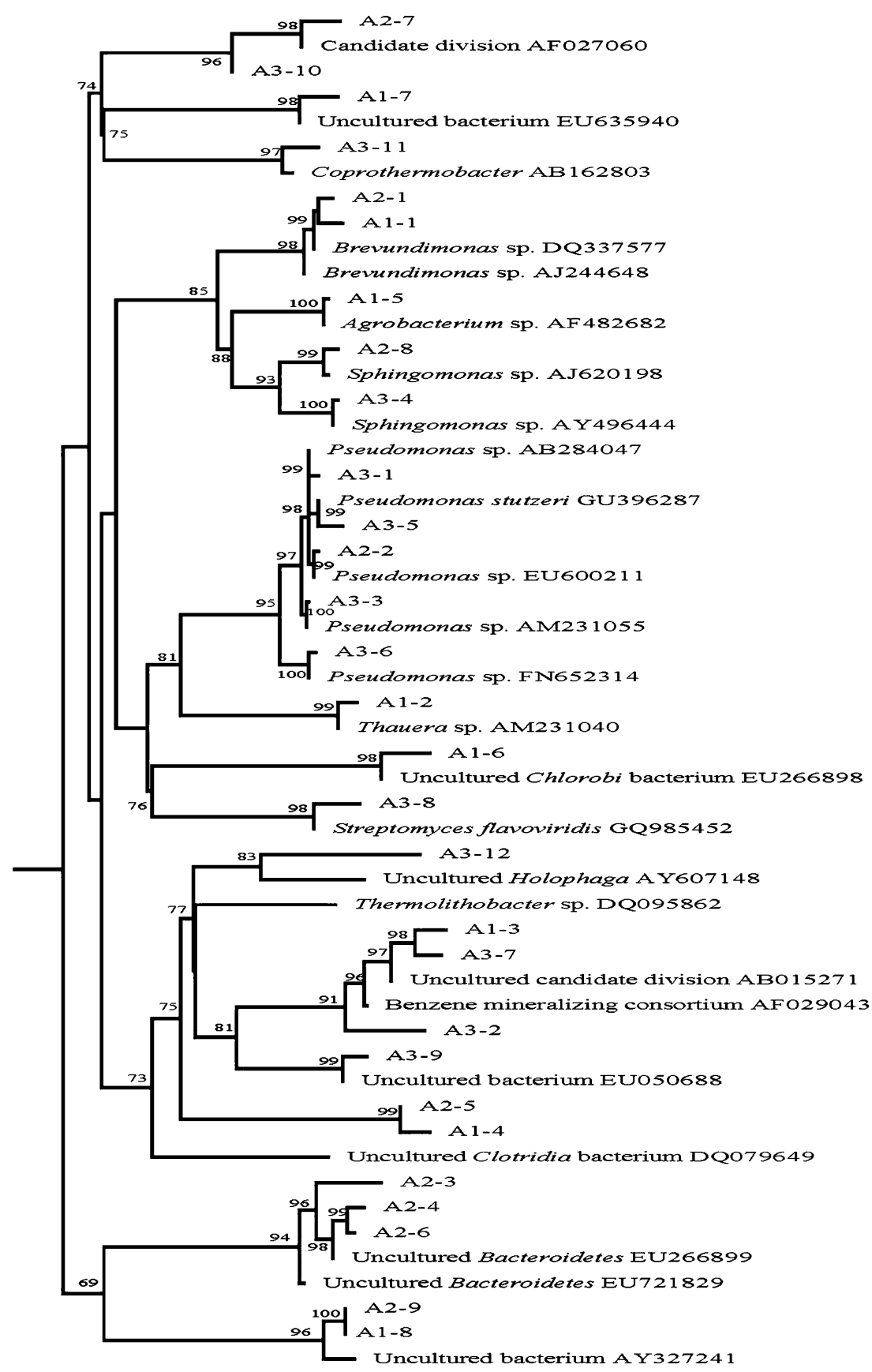

nities in B3 were Acinetobacter and Sphingomonas and uncultured bacterium.

\section{Rarefaction curves analysis}

Rarefaction curves of the clone libraries of six enrichment cultures and six oil-water samples tended to approach the saturation plateau at the range of 50 and 100 positive clones, respectively, indicating that collected positive clones in libraries could well cover the diversity of bacteria (Figs. 4 and 5).

Response of microbial community structure to microbial plugging

Microbial communities in the samples of the two studied wells varied regularly. For the samples from Well B2-4P47, uncultured bacteria-affiliated sequences were identi- 
Fig. 3 Phylogenetic tree of bacteria 16S rDNA phylotypes of clone libraries $B 1, B 2$, and $B 3$ constructed from oil-water samples from oil production well of B2-D5-P35. The tree was based on partial $16 \mathrm{~S}$ rDNA genes (approximately $800 \mathrm{bp}$ ) and the nearest clones retrieved from GenBank database. Bootstrap values $(>60 \%)$ are attached at branch points. The scale bar represents $5 \%$ estimated sequence divergence

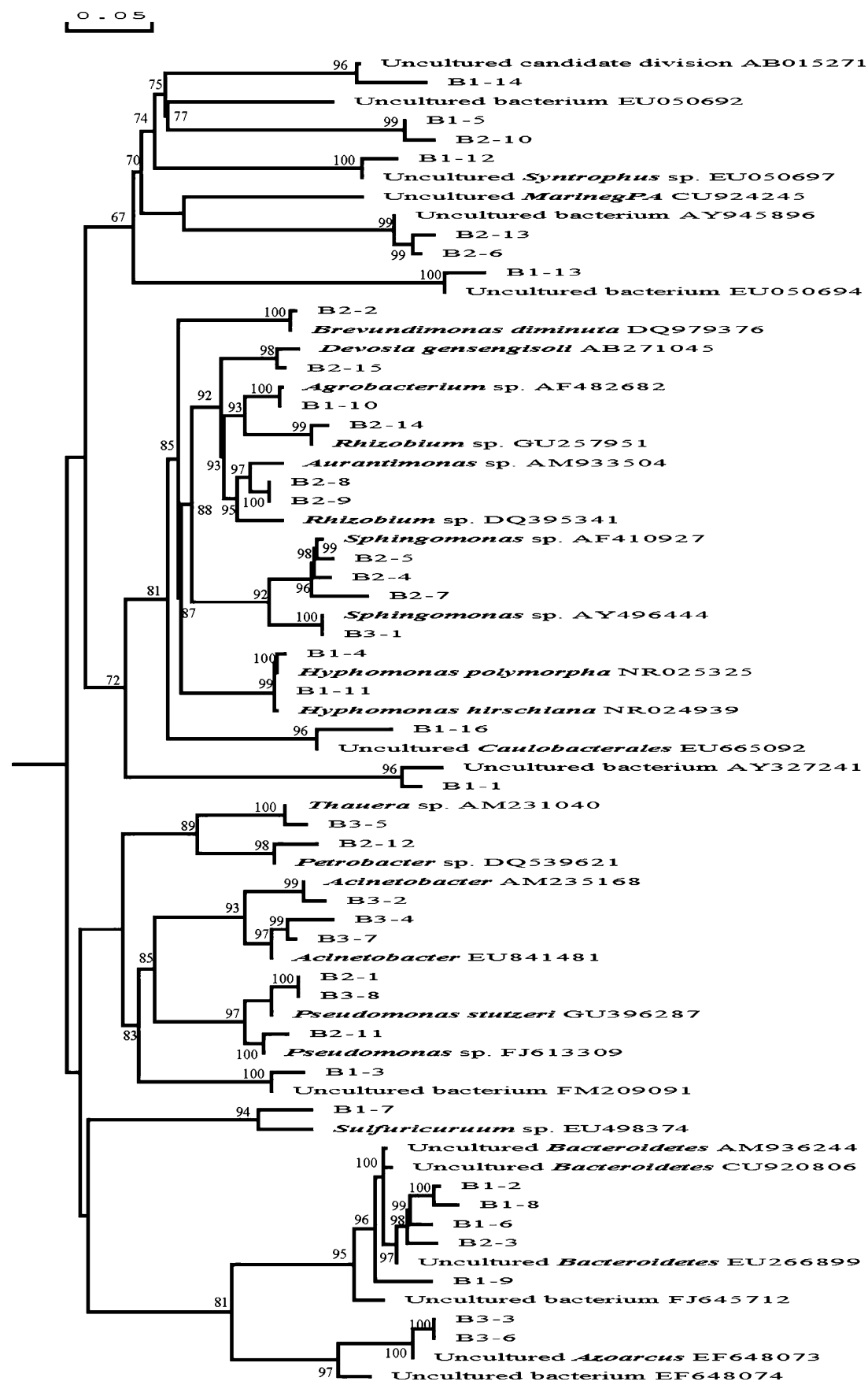

fied in clone libraries A1, A2, and A3 at 16\%, 13\%, and $25 \%$ of the total population, respectively. Before microbial plugging, few sequences was assigned to Pseudomonas in clone library A1, but after the field trial, the ratio of Pseudomonas-affiliated sequences rose to $13 \%$ in clone library A2 and reached $56 \%$ in the A3 library. Similarly, Sphingomonas-affiliated bacteria were not detected in the samples collected before the field trial, but after microbial plugging in the reservoir, Sphingomonas-affiliated sequences appeared in clone library A2 (1\%) with an increase to $11 \%$ in clone library A3. By contrast, Brevundimonas- affiliated sequences were predominant in the A1 (71\%) and A2 (61\%) clone libraries; however, in the A3 library, Brevundimonas-affiliated sequences disappeared (Fig. 6), which indicated that with the injection of fermentative medium for biopolymer producing bacteria in the oil reservoir microbial communities of Pseudomonas and Sphingomonas were activated while the growth of Brevundimonas was inhibited.

For the samples from Well of B2-D5-P35, uncultured bacteria accounting for $84 \%$ of all sequences in clone library B1 were absolutely dominant before microbial plugging, but 


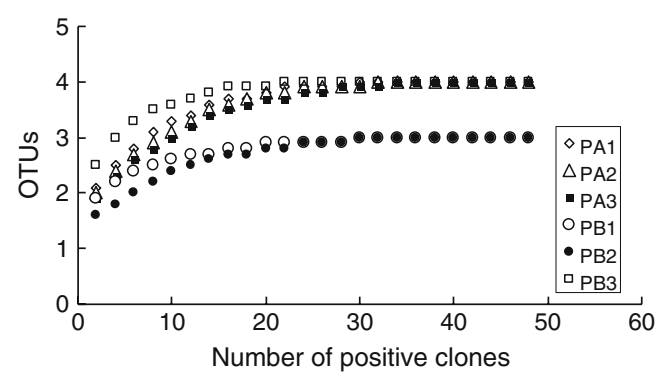

Fig. 4 Rarefaction analysis of 16S rRNA gene positive clones for clone libraries of biopolymer producing bacterial enrichment cultures $P A 1, P A 2, P A 3, P B 1, P B 2$, and $P B 3$ using software of Analytic Rarefaction

the fraction of uncultured bacteria-affiliated sequences dropped tremendously to $20 \%$ after the field trial, suggesting that the nutrients injected to the studied oil reservoir selectively enhanced the growth of cultured bacteria, as the cultured degree of microbial communities in the oil reservoir was improved. The stimulated cultured bacterial communities were primarily composed of Sphingomonas, Pseudomonas, and Acinetobacter. Although no Sphingomonas, Pseudomonas, and Acinetobacter lineages were detected in the sample before the field trial, Sphingomonas-affiliated sequences appeared in the B2 and B3 libraries, representing $18 \%$ and $33 \%$ of total sequences, respectively; a large proportion of the sequence $(42 \%)$ in the B2 library was related to Pseudomonas, but the proportion decreased to $3 \%$ in the B3 library; Acinetobacter lineage were only detected in the sample collected 2 months after microbial plugging commenced, with a significant contribution (44\%) to the B3 library (Fig. 6).

\section{Discussion}

The principal contributions of this study were to detect the growth of injected bacteria, find out the response of microbial communities to microbial plugging in the studied oil reservoir, and identify the differences between microbial communities

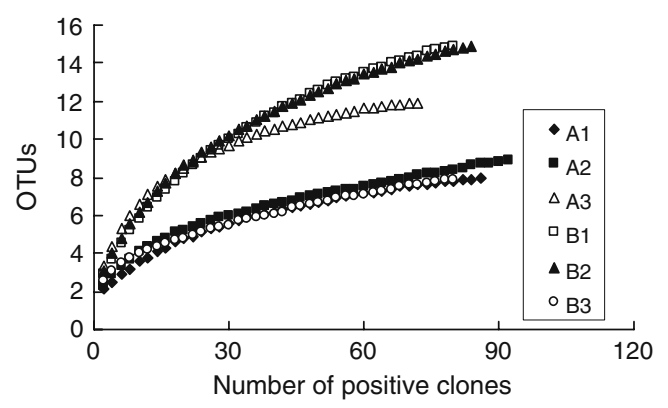

Fig. 5 Rarefaction analysis of 16S rRNA gene positive clones for clone libraries of oil-water samples of $A 1, A 2, A 3, B 1, B 2$, and $B 3$ using software of Analytic Rarefaction activated in the laboratory and in the natural environment by applying microbial molecular study methods.

It is undeniable that experimental studies, carried out in the laboratory, provide basic parameters to guide applications in various fields; however, it is also notable that results obtained from actual performance are not always similar with those obtained in the laboratory due to environmental factors that are unaccounted in the laboratory. In this study, microbial communities of B. agri, B. licheniformis, and P. aeruginosa appeared in enrichment cultures of biopolymer producing bacteria in the laboratory, offering further support that the fermentative medium can activate the growth of the targeted bacterium B. licheniformis. Compared with the microbial communities activated in the laboratory, bacteria activated in the studied oil reservoir were different; they included Pseudomonas, Sphingomonas, and Acinetobacter, but no B. licheniformis appeared. Reasons for the discrepancies likely relate to neglect the complex environmental factors of oil reservoirs. Firstly, the most easily overlooked environmental factor is strata pressure. Studies focusing on the effects of high pressures on extremely thermophilic deep-sea bacteria indicate that pressure exerts dominant control on the physiological behaviour and viability of the studied bacteria (Canganella et al. 1997; Bartlett 2002; Kaye and Baross 2004; Boonyaratanakornkit et al. 2007). In the case of oil reservoirs, a depth of approximately $2,000 \mathrm{~m}$ beneath the earth's surface has a pressure of $11.62 \mathrm{Mpa}$. Therefore, the environmental factor of strata pressure needs to be considered in the laboratory. Secondly, oxygen content is another environmental factor often neglected. In general, oil reservoirs, before exploitation, are identified as anaerobic environments; hence, they harbor mainly anaerobic and facultative microorganisms (Youssef et al. 2009). After being subjected to drilling and various production operations, oil reservoirs experience changes in oxygen content. As a result, microbial communities, especially those inhabiting the areas near the injecting wells, change in accordance with the change in oxygen environment (Lysnes et al. 2009). The studied oil reservoir has been producing oil for approximately 45 years; hence, oxygen contents in different parts of the reservoir are unknown and complex. However, enrichment cultures in the laboratory were carried out in stable aerobic conditions, leading to preferential growth of aerobic biopolymer-producing communities. Thirdly, cure oil and formation water appears to be another contributing environmental factor. The main fluids in oil reservoirs are cure oil and formation water, the former acting as a carbon or nitrogen source and the latter containing various volatile organic acids, salts and trace elements, which are believed to sustain the growth of a large number of isolates (Barth and Riis 1992; Magot et al. 2000; She et al. 2010). In this study enrichment cultures were grown in the freshwater medium 
Fig. 6 Relative abundances of bacterial community compositions in water-oil samples retrieved from wellheads of two production wells, B2-4-P47 and B2-D5-P35, in October 2008, February 2009, and June 2009, revealing the response of microbial communities before and after a field trial of microbial plugging in Daqing Oil Field (China)

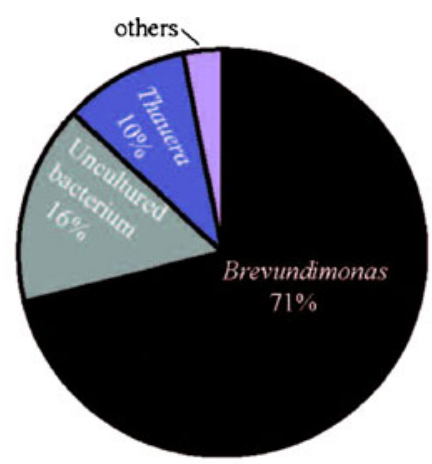

$10 / 2008$
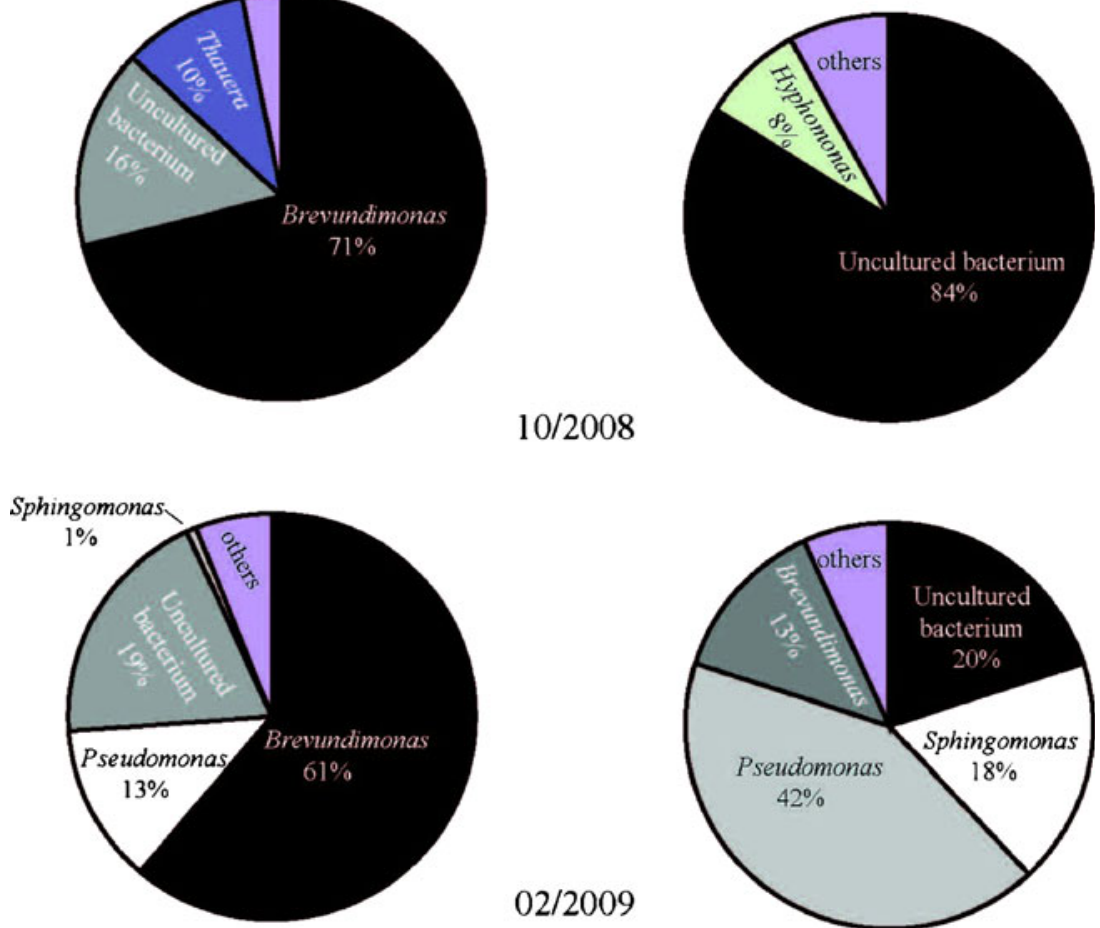

$02 / 2009$
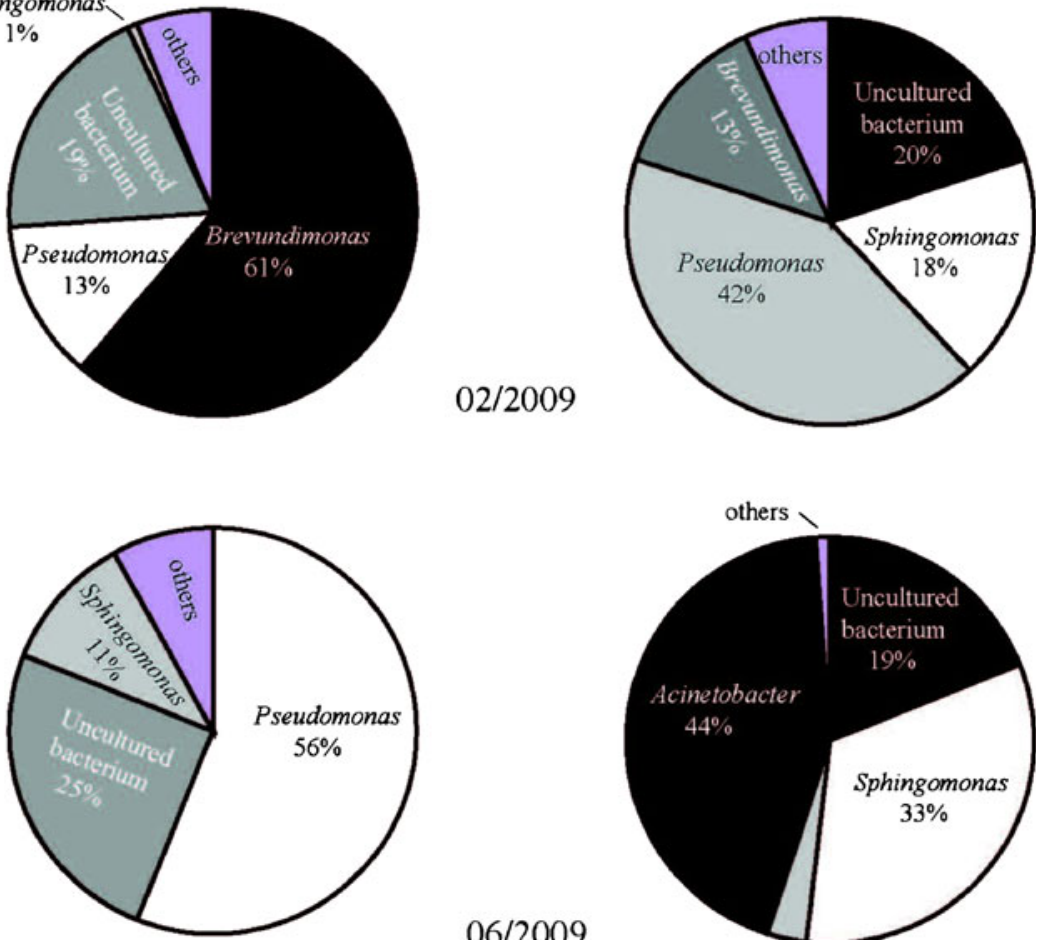

$06 / 2009$

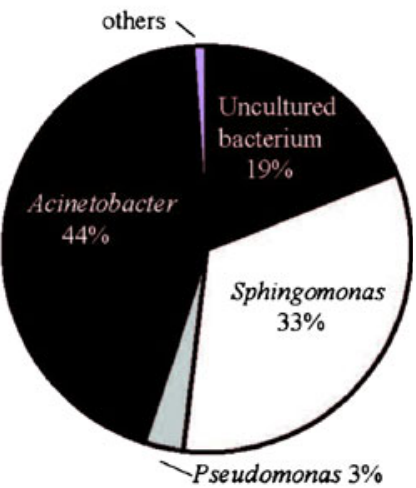

B ( B2-D5-P35)

\section{A ( B2-4-P47)}

ing nutrients, types of microbes in situ and types of microbes capable of growth or activation. Although activated microbial communities were not the predicted ones, oil production in the studied block increased by approximately 2,000 $\mathrm{t}$ (data provided by Daqing Petroleum Group Ltd.). Previous reports showed that Pseudomonas sp., known to degrade oil, can decrease oil viscosity (Jinfeng et al. 2005), and members of the genus Acinetobacter produce the most commonly used bioemulsifier called emulsan (Rosenberg and Ron 1999), which suggested that their presence among the activated microbial communities may have had the ability to enhance oil recovery.

Molecular analysis methods have emerged as important tools for discovering the microbial diversity of environ- 
mental populations. However, each method used has advantages and limitations (Cottrell et al. 2005). In this study, B. agri and B. licheniformis groups grew dominantly in the clone libraries of enrichment cultures, indicating these groups of microbes inhabited in the wellhead samples; however, B. agri and B. licheniformis-affiliated sequences were absent in the clone libraries of the wellhead samples. In addition, before microbial plugging, sequences belonging to Pseudomonas and Acinetobacter were not captured in clone libraries, while after microbial plugging; those microbial groups were activated and appeared. This showed that the various methods used have different types of biases in procedures of extraction of DNA (Feinstein et al. 2009), PCR amplification (Sipos et al. 2010), and TA clones (Taylor et al. 2007). Therefore, it is inevitable that some microbial groups will be missed using some techniques, especially, those having low abundance within the environmental samples. Pham et al. (2009) suggested that it is useful to apply more than one technique in microbial diversity studies.

In conclusion, given the environmental complexity of oil reservoirs, microbial communities in every layer of a reservoir appear to be different, and simulating the entire natural environment of an oil reservoir is infeasible. Activation of targeted bacterial communities is more difficult and survival of exogenous is lower in oil reservoirs than in the library. Thus, the performance of field trials of MEOR is not as easily measured as the enrichment culture and core tests carried out in the laboratory. Taking into account these differences, monitoring microbial communities in the reservoir before and during field applications may be a useful tool in monitoring the likelihood of occurrence or progression of MEOR activity and may become an essential guide for MEOR applications.

Acknowledgments This study was sponsored by the 863 Program (No. 2008AA06Z204) of the Ministry of Science and Technology, the National Natural Science Foundation (No.50974022) in P.R.China, and the program (No. DQYT-0503003-2006-JS-10257) of Daqing Oilfield Limited Liability Company of China National Petroleum Corporation. The authors wish to thank Engineers in the Daqing Oil Field, for kindly collecting samples and providing geo-materials of the studied block.

\section{References}

Abdul HJ, Farouq Ali SM (2003) Combined polymer and emulsion flooding methods for oil reservoirs with a water leg. J Can Pet Technol 42:35-40

Bailey SA, Bryant RS, Duncan KE (2000) Design of a novel alkalophilic bacterial system for triggering biopolymer gels. J Ind Microbiol Biotechnol 24:389-395

Banat IM (1995) Biosurfactants production and use in microbial enhanced oil recovery and pollution remediation: a review. Bioresour Technol 51:1-12
Banat IM, Franzetti A, Gandolfi I, Bestetti G, Martinotti MG, Fracchia L, Smyth TJ, Marchant R (2010) Microbial biosurfactants production, applications and future potential. Appl Microbiol Biotechnol 87:427-444

Barth T, Riis M (1992) Interactions between organic acid anions in formation waters and reservoir mineral phases. Org Geochem $19: 455-482$

Bartlett DH (2002) Pressure effects on in vivo microbial processes. Biochim Biophys Acta 1595:367-381

Boonyaratanakornkit BB, Miao Li Yan, Clark DS (2007) Transcriptional responses of the deep-sea hyperthermophile Methanocaldococcus jannaschii under shifting extremes of temperature and pressure. Extremophiles 11:495-503

Brown LR (1984) Method for increasing oil recovery. U. S. Patent Office. Patent No. 4,475,590

Brown LR, Vadie AA, Stephens JO (2002) Slowing production decline and extending the economic life of an oil field: New MEOR technology. SPE Res Eval Eng 5:33-41

Canganella F, Gonzalez JM, Yanagibayashi M, Kato C, Horikoshi K (1997) Pressure and temperature effects on growth and viability. Arch Microbiol 168:1-7

Cheng J, Li W, Zhang J, Wu J, Yang Z, Gou C (2007) Studies on the pilot test with microbial profile modification after polymer flooding in Daqing Oilfield. IPTC 11227. Proceedings of International Petroleum Technology Conference. Dubai, U. A. E

Cottrell MT, Waidner LA, Yu LY, Kirchman DL (2005) Bacterial diversity of metagenomic and PCR libraries from the Delaware River. Environ Microbiol 7:1883-1895

Dahle H, Garshol F, Madsen M, Birkeland NK (2008) Microbial community structure analysis of produced water from a hightemperature North Sea oil-field. Antonie Leeuwenhoek 93:37-49

Feinstein LM, Sul WJ, Blackwood CB (2009) Assessment of bias associated with incomplete extraction of microbial DNA from soil. Appl Environ Microbiol 75:5428-5433

Grabowski A, Nercessian O, Fayolle F, Blanchet D, Jeanthon C (2005) Microbial diversity in production waters of a lowtemperature biodegraded oil reservoir. FEMS Microbiol Ecol $54: 427-443$

Jinfeng L, Lijun M, Bozhong M, Rulin L, Fangtian N, Jiaxi Z (2005) The field pilot of microbial enhanced oil recovery in a high temperature petroleum reservoir. J Pet Sci Eng 48:265-271

Kaye JZ, Baross JA (2004) Synchronous effects of temperature, hydrostatic pressure, and salinity on growth, phospholipid profiles, and protein patterns of four Halomonas species isolated from deep-sea hydrothermal-vent and sea surface environments. Appl Environ Microbiol 79:6220-6229

Khachatoorian R, Petrisor IG, Kwan CC, Yen TF (2003) Biopolymer plugging effect: Laboratory-pressurized pumping flow studies. J Pet Sci Eng 38:13-21

Lagacé L, Pitre M, Jacques M, Roy D (2004) Identification of the bacterial community of maple sap by using amplified ribosomal DNA (rDNA) restriction analysis and rDNA sequencing. Appl Environ Microbiol 70(4):2052-2060

Li H, Yang SZ, Mu BZ, Rong ZF, Zhang J (2007) Molecular phylogenetic diversity of the microbial community associated with a high-temperature petroleum reservoir at an offshore oilfield. FEMS Microbiol Ecol 60:74-84

Lysnes K, Bødtker G, Torsvik T, Eva Ø, Bjørnestad ES (2009) Microbial response to reinjection of produced water in an oil reservoir. Appl Environ Microbiol 83:1143-1157

Maezumi S, Ono K, Shutao HK, Chao ZS, Enomoto H, Hong CX (1998) The MEOR field pilot in Fuyu Oilfield, China: a status review. Proceedings of 19th IEA Workshop and Symposium, Carmel, CA. International Energy Agency, Paris, France

Magot M, Ollivier B, Patel BKC (2000) Microbiology of petroleum reservoirs. Anton Leeuw Int J G 77:103-116 
Nagase K, Zhang ST, Asami H, Yazawa N, Fujiwara K, Enomoto H, Hong CX, Laing CX (2001) Improvement of sweep efficiency by microbial EOR Process in Fuyu Oilfield, China. SPE 68720. Proceedings of SPE Asia Pacific Oil and gas Conference and Exhibition. Society of Petroleum Engineers, Richardson, Texas

Nagase K, Zhang ST, Asami H, Yazawa N, Fujiwara K, Enomoto H, Hong CX, Laing CX (2002) A successful test of microbial EOR process in Fuyu Oilfield, China. SPE 75238. Proceedings of SPE/ DOE Improved Oil Recovery Symposium. Society of Petroleum Engineers, Richardson, Texas

Ohno K, Maezumi S, Sarma HK, Enomoto H, Hong C, Tohoku, Zhou SC, Fujiwara K (1999) Implementation and performance of a microbial enhanced oil recovery field pilot in FuYu Oilfield, China. SPE 54328. Proceedings of Asia Pacific Oil and Gas Conference and Exhibition, Jakarta, Indonesia

Orphan VJ, Taylor LT, Hafenbradl D, Delong EF (2000) Culturedependent and culture-independent characterization of microbial assemblages associated with high temperature petroleum reservoirs. Appl Environ Microbiol 66:700-711

Pham VD, Hoatow LL, Zhang S, Fallon RD, Jackson SC, Tomb J-F, Delong EF, Keeler SJ (2009) Charactering microbial diversity in production water from an Alaskan mestothermic petroleum reservoir with two independent molecular methods. Environ Microbiol 11(1):172-187

Planckaert M (2005) Oil reservoirs and oil production. In: Ollivier B, Magot M (eds) Petroleum microbiology. ASM, Washington, pp 3-20

Rosenberg E, Ron EZ (1999) High- and low-molecular-mass microbial surfactants. Appl Microbiol Biotechnol 52:154-162

She YH, Zhang F, Xia JJ, Kong SQ, Wang ZL, Shu FC, Hu JM (2010) Investigation of biosurfactant-producing indigenous microorganisms that enhance residue oil recovery in an oil reservoir after polymer flooding. Appl Biochem Biotechnol. doi:10.1007/s12010-010-9032-y
Sheehy AJ (1991) Development and field evaluation of a new microbial EOR concept. APEA J 31:386-390

Sheehy A (1992) Recovery of oil from oil reservoirs. US patent office. Patent No. 5,083,610

Sipos R, Székely A, Révész S, Márialigeti K (2010) Addressing PCR biases in environmental microbiology studies. Methods Mol Biol 599:37-58

Stewart TL, Fogler HS (2001) Biomass plug development and propagation in porous media. Biotechnol Bioeng 72:353-363

Stewart TL, Fogler HS (2002) Pore-scale investigation of biomass plug development and propagation in porous media. Biotechnol Bioeng 77:577-588

Taylor DL, Herriott IC, Long J, O’Neill K (2007) TOPO TA is A-OK: a test of phylogenetic bias in fungal environmental clone library construction. Environ Microbiol 9(5):1329-1334

Usman A (2009) Microbial plugging: a cost-effective approach for improved sweep efficiency through permeability reduction. SPE 119023. Proceedings of Production and Operations Symposium. Oklahoma, USA

Vossoughi S (2000) Profile modification using in situ gelation technology-a review. J Pet Sci Eng 26:199-209

Yakimov MM, Amro MM, Bock M, Boseker K, Fredrickson HL, Kessel DG, Timmis KN (1997) The potential of Bacillus licheniformis strains for in situ enhanced oil recovery. J Pet Sci Eng 18:147-160

Youssef N, Elshahed MS, McInerney MJ (2009) Microbial process in oil field: culprits, problems, and opportunities. Adv Appl Microbiol 66:141-251

Zhang F, She YH, Zheng Y, Zhou ZF, Kong SQ, Hou DJ (2010) Molecular biologic techniques applied to the microbial prospecting of oil and gas in the Ban 876 gas and oil field in China. Appl Microbiol Biotechnol 86:1183-1194 